\title{
LEARNING GREEK IN LATE ANTIQUE GAUL
}

\section{INTRODUCTION}

Greek had held an important place in Roman society and culture since the late Republican period, and educated Romans were expected to be bilingual and well versed in both Greek and Latin literature. The Roman school ‘curriculum' was based on Hellenistic educational culture, and in the De grammaticis et rhetoribus Suetonius says that the earliest teachers in Rome, Livius and Ennius, were 'poets and half Greeks' (poetae et semigraeci), who taught both Latin and Greek 'publicly and privately' (domi forisque docuisse) and 'merely clarified the meaning of Greek authors or gave exemplary readings from their own Latin compositions' (nihil amplius quam Graecos interpretabantur aut si quid ipsi Latine composuissent praelegebant, De gramm. 1-2). ${ }^{1}$ Cicero, the Latin neoteric poets, and Horace are obvious examples of bilingual, educated, Roman aristocrats, but also throughout the imperial periods, a properly educated Roman would be learned in utraque lingua. ${ }^{2}$ The place of Greek in Quintilian's Institutio Oratoria reveals the importance and prevalence of Greek in Roman education and

${ }^{1}$ R. Kaster (ed., trans.), C. Suetonius Tranquillus : De Grammaticis et Rhetoribus (Oxford, 1995).

${ }^{2}$ For the use of utraque lingua to denote knowledge of Greek and Latin literature, see, among others, Hor. Carm. 3.8.5, Sat. 1.10.23-4 ; Cic. Arch.; Ov. Ars. Am. 2.122; Quint. Inst. 1 pr. 1, 1.1.14; Plin. Ep. 8.25.4, 3.1.7, 7.25.4; Gell. NA 17.5.3, 9.15.2; Mart. 10.76.6; August. De civ. D. 8.12; Tert. Adversus Praxean 3; Amm. Marc. 18.5.1. See also Plin. Ep. 7.9.1-2 to Fuscus, in which he advises how to study at his villa and translate between Latin and Greek, and 9.36.3, to Fuscus, in which he describes his own daily routine of reading a Greek or Latin oration aloud. 
literature in the late first century A.D.. Quintilian argues that children should learn both Greek and Latin but that it is best to begin with Greek. ${ }^{3}$ Famously, in the second century A.D. the Roman author Apuleius gave speeches in Greek to audiences in Carthage, and in his Apologia mocked his accusers for their ignorance of Greek. ${ }^{4}$

This article examines the status of Greek teaching in Gaul in Late Antiquity, showing that knowledge of and interest in Greek persisted, and that it continued to be taught in this period. It challenges our conventional narrative, arguing that the methodology that has so far mainly yielded negative impressions about Greek knowledge in the late antique West is problematic. This article consists of three main sections. The first addresses the lacunae in our current understanding, showing that the decline of Greek teaching in Gaul was not as drastic or early as often assumed. The second presents a new interpretation of the sources available from fourth century Gaul, focusing on the works of the grammarian and Gallo-Roman

${ }^{3}$ Quint. Inst. 1.1.12-14. He also provides a suggested reading list of the Greek authors, including Homer, Demosthenes, non-dramatic poets, and authors of comedy, tragedy, history, oratory, and philosophy (Inst. 10.1.39; 10.1.46-84; 10.1.105-6). We get another example of the sorts of texts taught by Greek grammarians in the West from Statius, whose father (Papinius Statius) was a teacher near Naples. He taught Homer, Hesiod, Sappho, Alcman, Corinna, Stesichorus, Pindar, Ibycus, Callimachus, and Lycophron (Stat. Silv. 5.3.146-8). On this topic see C. McNelis, 'Greek grammarians and Roman society during the Early Empire: Statius' father and his contemporaries', ClAnt 21 (2002), 67-94. Papinius Statius' curriculum may betray his own interests and options of someone who lived in a traditionally Greek-speaking area and may not necessarily be representative of all classical schools. Cf. F. Ciccolella, Donati Graeci: learning Greek in the Renaissance (Leiden, 2008), 126-7.

${ }^{4}$ Apul. Flor. 18.15-16; Apol. 30.11, 87.4. 
politician Ausonius, legislation from the Codex Theodosianus, and a late-antique school text, the Colloquium Celtis. These sources make clear that Greek remained an integral part of Roman education in this period. The final section tests this new interpretation with a case study of the teaching practices of Sapaudus, a fifth-century Latin rhetor in Vienne, through a closereading of a letter from the priest Claudianus Mamertus.

\section{CORRECTING OUR FLAWED METHODOLOGY FOR GAUGING KNOWLEDGE OF GREEK IN THE LATIN WEST}

Despite the deep-rooted importance of Greek in Roman education and literary culture, surprisingly little scholarly attention has been paid to the question of Greek in the late antique West. There has been a great deal of research on Greek teaching in the Early Middle Ages and Renaissance, ${ }^{5}$ and much interest in bilingualism and Latin learning in the late antique East, ${ }^{6}$

${ }^{5}$ E.g. W. Aerts, 'The knowledge of Greek in western Europe at the time of Theophano and the Greek grammar fragment in ms. Vindobonensis 114,' in V. van Aalst and K. Ciggaar (edd.), Byzantium and the Low Countries in the Tenth Century. Aspects of Art and History in the Ottonian Era (Hernen, 1985), 78-103; W. Berschin (trans. J. Frakes), Greek Letters and the Latin Middle Ages (Washington, 1988); Ciccolella (n. 3); M. Herren and S. Brown (edd.), The Sacred Nectar of the Greeks: the Study of Greek in the West in the Early Middle Ages (London, 1988); M. Herren, 'Pelasgian fountains: learning Greek in the Early Middle Ages', in E. Archibald, W. Brockliss, and J. Gnoza (edd.), Learning Latin and Greek from Antiquity to the Present (Cambridge, 2015), 65-82; B. Kaczynski, Greek in the Carolingian Age: The St. Gall Manuscripts (Cambridge, MA, 1988).

${ }^{6}$ E. Dickey, Learning Latin the Ancient Way: Latin Textbooks from the Ancient World (Cambridge, 2016); E. Dickey, 'Teaching Latin to Greek speakers in antiquity', in E. 
but there exists no focused study of the role of Greek in the education and literary culture of late antique Gaul, or the West more generally.

Such lack of investigation of the topic probably stems from the traditional scholarly narrative, which assumes that knowledge of Greek was sharply declining or had virtually disappeared in the West by Late Antiquity. This view is central to the arguments of canonical works on education and literary culture of Late Antiquity, such as Henri Marrou's 1948 Histoire de l'éducation dans l'Antiquité, and Pierre Riché's 1976 Éducation et culture dans l'Occident barbare: $v i^{e}$ et viii ${ }^{e}$ siècles, and has thus been perpetuated throughout scholarship of the twentieth and twenty-first century. ${ }^{7}$ The resulting consensus ensured that by now it is

Archibald, W. Brockliss, and J. Gnoza (edd.), Learning Latin and Greek from Antiquity to the Present (Cambridge, 2015), 30-51; F. Millar, A Greek Roman Empire: Power and Belief under Theodosius II (408/450) (Berkeley, 2006); J. Adams, Bilingualism and the Latin Language (Cambridge, 2003).

${ }^{7}$ Cf. H. Marrou (trans. G. Lamb), A History of Education in Antiquity (New York, 1956), 354: 'In the West, Greek was gradually dying out'; P. Riché (trans. J. Contreni), Education and Culture in the Barbarian West (Columbia, SC, 1976), 44: 'There were simply not enough people who could read Greek or who were even interested in the translations produced during this period'. T. Haarhoff, Schools of Gaul: A Study of Pagan and Christian Education in the Last Century of the Western Empire (London, 1920), 224, argues that although Ausonius and Paulinus of Pella mentioned Greek education in the schools of fourth-century Gaul, we cannot assume that this instruction indicates 'thoroughness or efficiency'. P. Riché, 'Le Grec dans les centres de culture d'Occident', in M. Herren and S. Brown (n.5), 143-168, at 145, blames the shock of the barbarian invasions, saying that while the schools closed, some aristocrats continued to learn Greek at home; cf. A. Jones, The Later Roman Empire 284-602: A Social, 
common practice to interpret any glimmer of Greek in late western sources in a pessimistic light; any references or allusions to Greek texts and authors in late antique Latin literature are usually dismissed as superficial or as the products of Latin intermediaries - that is, Latin translations, summaries, and re-workings of Greek texts - without considering alternative explanations for a Latin author's engagement with Greek sources.

The methodology that has yielded these conclusions examines how late Latin authors directly engage with the traditional Greek literary canon - that is, through their direct allusions, references, and quotations of Greek authors in Latin texts. A notable proponent of this approach was Pierre Courcelle, who employed it in his seminal Les lettres grecques en occident (1948). Though he suggests that there was a 'renaissance' of Greek in Gaul in the 470s, he argues that overall there was no sustained or consistent knowledge of Greek among educated Gauls at any point in Late Antiquity, neither among literary circles nor in clerical or monastic centres. ${ }^{8} \mathrm{~A}$

Economic, and Administrative Survey, 3 vols. (Oxford, 1964), 987, 'In the fifth century boy in aristocratic homes still learnt Greek...It may be doubted, however, whether Greek continued to form part of the regular curriculum taught in the schools'. See also I. Gualandri, " Quid erat causae cur Graecas litteras oderam?' Il greco in Occidente tra IV e V secolo d.C.' in Modelli di un multiculturalismo giuridico : il bilinguismo nel mondo antico : diritto, prassi, insegnamento (Naples, 2013), 675-701, for the place of Greek in the West, though she focusses almost exclusively on the fourth century in Italy, and emphasizes mainly the use of Greek for access to Christian texts.

${ }^{8}$ P. Courcelle (trans. H. Wedeck), Late Latin Writers and their Greek Sources (Cambridge MA, 1969), 224-70. In the first edition of his work (1943) Courcelle linked this so-called renaissance in Gaul to the fact that the easterner Anthemius had been made emperor in the 
re-examination of Latin texts from Late Antiquity shows that this traditional methodology for gauging knowledge of Greek in Latin texts is fundamentally flawed, and that we need to reassess our assumptions about the role and place of Greek in late Latin literature and education.

For example, the traditional methodology falls short when examining the Latin works by Ausonius, a fourth-century Gallo-Roman who taught grammar and rhetoric in Bordeaux for thirty years before becoming tutor to the young Gratian, and later holding the high offices of Praetorian Prefect of Gaul and the consulship. If we employ Courcelle's approach to Ausonius' extant Latin works, that is, if we only look at the direct allusions, references and quotations of Greek authors in his work, we might assume that Ausonius knew and read very little Greek. He clearly had read some Greek epigrams and Homer, but there is no direct evidence in his extant Latin literary output to suggest that he was familiar with Greek tragedy or Old Comedy, philosophy, nor any prose authors except perhaps Herodotus. ${ }^{9}$ In fact, judging solely by how Ausonius engages directly with the Greek literary canon in his Latin poetry and prose, we could conclude that he had a very limited Greek reading repertoire, which is conventionally equated with a limited knowledge of the Greek language. This conclusion is problematic because we know that Ausonius was able to read and write in Greek. Although he claims that he was a poor

West but tempered this assertion in the second edition (1948), after much skepticism from his readers. The translation by Wedeck in 1969 is of Courcelle's second edition.

${ }^{9}$ For Ausonius' Greek see R. Green, 'Greek in Late Roman Gaul: the evidence of Ausonius', in E. Craik (ed.), Owls to Athens: Essays on Classical Subjects Presented to Sir Kenneth Dover (Oxford, 1990), 311-19; B. Goldlust, 'Le statut de la culture grecque dans la poétique d'Ausone', Latomus 69 (2010), 129-49. Text and abbreviations of Ausonius follow R. Green, The works of Ausonius: edited with an introduction and commentary (Oxford, 1991). 
Greek student as a boy, ${ }^{10}$ by adulthood he was able not only to play with Greek language and forms in many of his Latin poems, but even to translate Greek poems into Latin, and write in Greek.

Ausonius composes, or translates, three poems completely in Greek, while in two other poems the lines alternate between Latin and Greek (Epigr. 21, 47, 49, 50, 51),${ }^{11}$ and he employs Greek phrases throughout his Ludus Septem Sapientum. ${ }^{12}$ In letters to Axius Paulus, a rhetor in Bordeaux, Ausonius often composes lines or even whole sections in Greek. In one letter to Paulus, the famous 'macaronic' letter, Ausonius switches back and forth seamlessly between Latin and Greek for forty-five lines, sometimes mid-word (Ep. 8). ${ }^{13}$ Elsewhere Ausonius shows off his poetic virtuosity and firm grasp of Greek by composing playful poems about the Greek alphabet. The schoolmaster Eunus uses different letters of the Greek alphabet to describe (among other things) giving oral sex to a woman (Epigr. 87) and in another poem Ausonius

10 At Prof. 8.13-16, where Ausonius celebrates his childhood Greek teachers, he says he struggled with the language (obstitit nostrae quia, credo, mentis | tardior sensus neque disciplinis | adpulit Graecis puerilis aeui | noxius error). Augustine also confessed difficulty learning Greek as a boy, and he disliked the language and the way it was taught (August. Conf. 1.13.20-3).

11 For Ausonius' epigrams see N. Kay, Ausonius Epigrams: Text with Introduction and Commentary (London, 2001).

${ }^{12}$ Greek phrases are usually used for each of the sage's 'sayings', e.g. Delphis Solonem scripse

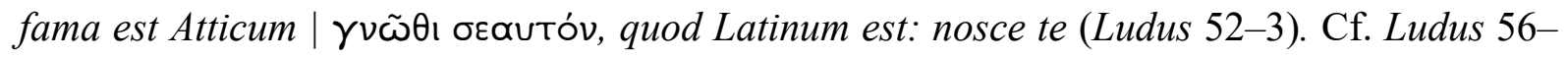
90 (passim), 138, 149, 156, 180, 189, 203, 215.

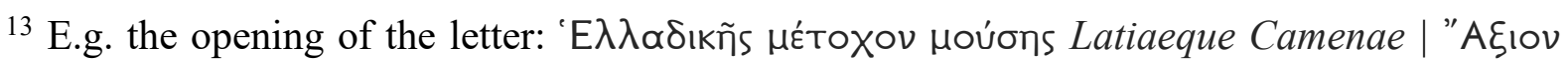
Aưoóvios sermone adludo bilingui (Ep. 6.1-2). 
composes riddles for the monosyllabic letters of the Greek and Latin alphabets (Technop. 13). Although Ausonius' playfulness with Greek does not necessarily indicate that he was completely fluent, it nevertheless demonstrates that he was more than comfortable with the language, especially insofar as he could use it to translate into Latin. More importantly, Ausonius' use of Greek in his Latin compositions indicates that he expected his readers and audience to be able to read his Greek phrases and short poems and understand his jokes, and that there were copies of some Greek works available in late antique Bordeaux for men like Ausonius to peruse, learn from, and imitate. ${ }^{14}$

The contradiction between Ausonius' evident knowledge of Greek and his lack of direct engagement with Greek authors in his work raises two important questions: first, was Ausonius in fact conversant with more of the Greek canon than comes across in his writing? And second, if he was not, how do we explain the fact that he clearly did read and understand at least basic Greek? What did 'knowing Greek' mean to Ausonius and his contemporaries, and what role did Greek play in their formal education and literary endeavours?

\footnotetext{
${ }^{14}$ Ausonius' own Greek compositions would provide further opportunities for contemporary and later audiences to interact with Greek. For example, M. Onorato, 'Un ospite per Apollo: intertesualità interna e codice ausoniano nella metatoria pagina di Sidonio a Lampridio', BStudLat 48 (2018), 492-523, at 517-20 argues that Sidonius draws on Ausonius' bilingual letter to Paulus in his own composition for his friend, the teacher Lampridius (Sid. Ep. $8.11 \mathrm{vv}$. 1-55;). It is natural that the litterati of fifth century Bordeaux (and beyond) would be intimately familiar with Ausonius' work, especially those in the teaching profession, such as Lampridius. For Lampridius' teaching career, cf. Sid. Ep. 8.9, 8.11, 9.13, Carm. 9.311-15.
} 


\section{THE EVOLVING PLACE OF GREEK IN CLASSROOMS OF FOURTH-}

\section{CENTURY GAUL}

Looking to ancient technical materials, such as grammars, commentaries, and colloquia can help to shed light on some of these questions and may point to larger trends in the changing role of Greek in late western classrooms. Félix Racine, for example, has argued that the use of Greek in Servius' commentary on Virgil from the late fourth or early fifth century indicates that Greek was used as a pedagogical tool for Latin education in the West in Late Antiquity. ${ }^{15}$ It is clear through the many technical grammatical terms and Greek citations in his commentary that Servius himself was able to read and thoroughly understand Greek. It seems, though, that much of Servius' knowledge of classical Greek authors was governed by what was handed down through the grammatical tradition, and his commentary draws heavily on Donatus' earlier Virgilian commentary. Donatus' commentary is lost, but it was integrated with Servius by an Irish compiler in the Early Middle Ages, the result of which is referred to as Servius Auctus, DS, or Servius Danielis. ${ }^{16}$ DS shows that Donatus' commentary was large and not well suited to Servius' classroom. Therefore, the ways in which Servius engages with Donatus' commentary - that is, what he chooses to abbreviate, expand upon, or leave out in his own commentary - illustrate both his aims as teacher, and what he expected his students and readers

${ }^{15}$ F. Racine, 'Servius' Greek lessons', in P. Archibald, W. Brockliss, and J. Gnoza (edd.), Learning Latin and Greek from Antiquity to the Present (Cambridge, 2015), 52-64.

16 The best account for this is G. Goold, 'Servius and the Helen Episode', HSPh 74 (1970), 101-68. Also see R. Kaster, Guardians of Language: The Grammarian and Society in Latte Antiquity (Berkeley, 1988), 169-97; D. Fowler, 'The Virgil Commentary of Servius', in C. Martindale (ed.), Cambridge Companion to Virgil (Cambridge, 1997), 73-8. 
to know. ${ }^{17}$ How Servius deals specifically with Greek citations and references indicates how he perceived the role and use of Greek in his classroom. An example of how Servius interacts with the Greek material in Donatus' commentary is his entry on the adjective Trinacrius from book one of the Aeneid. Servius leaves out Donatus' discussion of the alternative Greek spelling of the word, and focusses rather on the correct Latin term, which was used by Virgil and later Latin poets, and he provides the Latin translation and explains the etymology of the Greek word. ${ }^{18}$ Furthermore, the most common Greek citations in Servius' commentary are about etymologies, mythography, orthography and scansion of Latin words, and technical Greek grammatical terms. In addition, Servius tends to evoke the names of Greek authors not for their own sake, but rather as authorities to support his own interpretations of language and as models for his students. Racine concludes that, while Servius himself clearly knew and read Greek well and expected at least a basic knowledge of Greek from his students and readers, it seems that Greek played a specific role in his teaching and his commentary. For Servius and his students, Greek language and literature was no longer read and taught solely for its own sake, but rather it was valued as a useful tool to help teach Latin and explain Latin texts. Servius' tendency to use Greek as pedagogical tool in his commentary may be symptomatic of a larger trend in the changing role of Greek in late antique education and literary culture. Greek had long been considered the foundation of Latin literature and mythology, so even when

\footnotetext{
${ }^{17}$ For how Servius' commentary on Virgil could be used in late antique classrooms, see F. Foster, 'Teaching language through Virgil in Late Antiquity', CQ 67 (2017), 270-83.

${ }^{18}$ Racine (n. 15), '54 : Serv. A. 1.196. TRINACRIO - Graecum est propter tria äkpa, id est promunturia, Lilybaeum, Pachynum, Pelorum. Latine autem Triquetra dicitur. (DS: sane

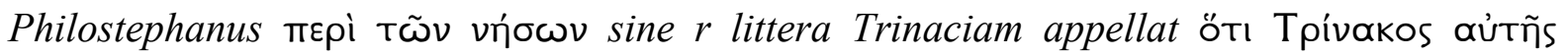
$\pi \rho \tilde{\omega} \operatorname{Tos} \varepsilon \dot{\beta} \alpha \sigma i ́ \lambda \varepsilon \cup \sigma \varepsilon \nu) '$.
} 
fluency in Greek and intimate knowledge of the literary canon gradually began to fade in Gaul, it is natural that interest in Greek persisted. Not only would elementary Greek language remain foundational in learning and reading Latin literature, but interest in and knowledge of Greek literature and culture would remain important to late Latin writers with literary ambitions.

A movement towards the more foundational role of Greek in Latin education may be apparent already in fourth-century sources from Gaul. Despite widespread doubts about knowledge of Greek in the late antique West, there is indeed ample evidence of Greek teaching in Gaul in the fourth century. The hesitations, or reluctance, of modern scholars to label such varied evidence as proof of knowledge of Greek can be alleviated by adopting a different approach to how we conceptualize the perceived value of Greek and an adapted definition of what exactly we mean by 'knowledge' of Greek in this period. The evidence of Greek teachers and students from the Colloquium Celtis, Ausonius, Paulinus of Pella, and the Codex Theodosianus shows that Greek was still being taught, but indicate that its place in Roman education had changed from how Quintilian had envisioned it in the first century A.D.

Elementary Greek lessons feature prominently in the school scenes from the Colloquium Celtis, a language-learning text that was probably in use in Gaul in the late third or fourth century. ${ }^{19}$ The colloquium describes two separate school environments; an elementary

19 Cf. E. Dickey, The Colloquia of the Hermeneumata Pseudodositheana II: Colloquia Harleianum, Montepessulanum, and Celtis (Cambridge, 2015), 141-266; A. Dionisotti, 'From Ausonius' schooldays? A schoolbook and its relatives', JRS 72 (1982), 83-125.The location in Gaul is based on inclusions and exclusions from the curriculum and linguistic features. The descriptions of urban life suggest a time during the later empire in a provincial centre that is not Rome. Certain food and clothing vocabulary places it in a cold climate, probably north of the Alps, and the mention of a certain grain, bracem, strongly suggests Gaul. Dickey, 159 
school for reading and writing and a more advanced school that taught Latin and Greek grammar and some rhetoric. ${ }^{20}$ Greek teachers and lessons are included in both school scenes. A Greek teacher is listed alongside teachers of arithmetic, shorthand, Latin, and rhetoric at the opening of the school scenes (18), ${ }^{21}$ and a Greek teacher is mentioned in parallel to a Latin grammarian at the end of the first scene of the elementary school and beginning of the secondary school scene $(29,30 a){ }^{22}$ We also have a potential reading list for the secondary

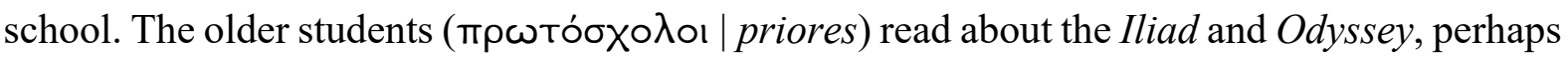

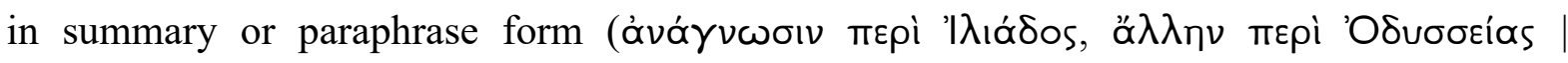
lectionem de Iliade, aliam de Odyssia, 37a), and other Greek texts listed include Theocritus, Thucydides, Demosthenes, Hippocrates, Xenophon, the Cynics, and possibly Menander. ${ }^{23}$ The

clarifies that the bilingual colloquium was probably in existence earlier, but that in late antique Gaul someone added an epilogue and edited or fixed parts that had been damaged or lost.

${ }^{20}$ It is possible that there are three schools described, but the last one is probably part of the first scene, and the secondary school section somehow got inserted into the middle of it. Cf. Dionisotti (n. 19), 120-1; Dickey (n. 19), 207.

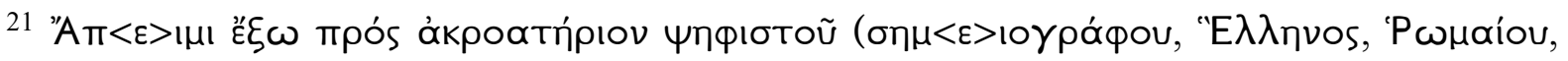
ṕńtopos). | Eo foras ad auditorium calculatoris (notarii, Graeci, Latini, oratoris).

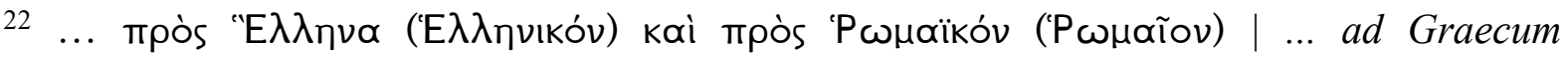

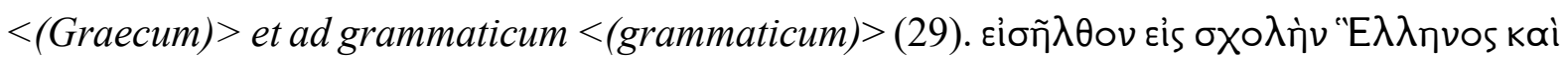

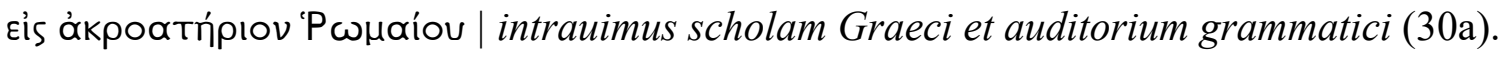

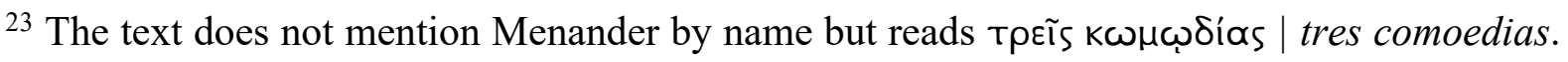
Since Terence is already named and is separated from the Greek authors in the list by Sallust, it is possible that this refers to Menander, rather than Plautus. Menander was a standard school text in the West. Cf. Dickey (n. 19), 224. 
reference to the Cynics probably refers to texts of philosophical sayings called chreiai, which were often centered around Diogenes, the 'founder' of the Cynics, and were often used in educational contexts. ${ }^{24}$ Alongside these Greek texts are Cicero, Virgil, Persius, Lucan, Statius, Terence, Sallust, and 'the two wars' (duo bella, 38a), which may refer to Caesar. ${ }^{25}$

The list of authors does not necessarily mirror what was taught in the schools, and it is possible that some of the authors were read as summaries or paraphrases, such as Homer and the works of the Cynics. For example, the inclusion of Persius, Lucan, and Statius in the Latin list, and Theocritus, Thucydides, Hippocrates, and Xenophon on the Greek side does not equate with our other evidence of schools texts in the late antique West. ${ }^{26}$ It is possible, as in other

${ }^{24}$ Cf. Dickey (n. 19), 224, who points out that many chreiai were not about Diogenes, and that the other texts in the list were long works, whereas chreiai were short and were mostly used as things to draw from and change in different school exercises. The reading list from $37 \mathrm{a}-38 \mathrm{c}$ is overall quite uneven, however, so it is possible that such handbooks of philosophical sayings is precisely what is meant here.

${ }^{25}$ Dionisotti (n. 19), 113 and Dickey (n. 19), 223 doubt that it could be Caesar since he was not a traditional school text, but in the sixth century Parthenius introduced the young Arator to the works of both Caesar and Sidonius (Arator, Ep. ad Parthen. 33-48), which may indicate that these works were sometimes read in such contexts.

${ }^{26}$ Both Thucydides and Xenophon are mentioned by Quintilian as useful for learning history, and he reports that Cicero saw them as useful for this purpose as well (Inst. 10.1.33), and also mentions Theocritus (Inst. 10.1.55). Hippocrates is mentioned by Sidonius in an educational context (Sid. Ep. 9.14.2), but this is possibly a rhetorical flourish rather than a report of an actual school text, as discussed below. It would be odd, though, if Homer, a standard school 
vocabulary lists in the colloquia, that some classical authors were added to the list for 'good measure', as it were. The colloquia by their very nature often have more words and options than is necessarily for phrases to make sense, precisely because their aim is to teach language, vocabulary, and inflection. ${ }^{27}$ At the same time, even when authors from late antique Gaul talk about education they rarely record exact details of classroom environments. Therefore, it is very possible that these texts were read in some classrooms, but that only the main authors, Cicero and Demosthenes, Homer and Virgil, Terence and Menander, are recorded in the offhand remarks of our late antique sources. Whether or not the reading list reflects reality, this colloquium clearly shows that there were Greek teachers in Gallo-Roman classrooms in Late Antiquity.

A pattern of widespread yet lower-level Greek teaching is also clearly evident in the careers of five Greek grammarians who taught in Bordeaux in the early- to mid-fourth century, whom Ausonius celebrates in his Commemoratio professorum Burdigalensium. Three of these, namely Corinthius, Spercheus, and Menestheus, won 'little profit and small praise' for their teaching (fructus exilis tenuisque sermo, Prof. 8.6), and taught younger students. Corinthius and Spercheus both taught Ausonius himself when he was young (primis... in annis, Prof. 8.10). Another Greek grammarian working in Bordeaux in the mid-fourth century was the Sicilian-born Citarius (Prof. 13). Judging by the familiar tone of the poem, Citarius may have been Ausonius' colleague, perhaps taking up a post previously held by Corintheus or Spercheus. Ausonius regarded Citarius as dignus inter grammaticos qui celebrere bonos ('worthy to be praised amongst good grammarians', Prof. 13.1-2) such as Zenodotus and

text, was read as a paraphrase or summary, and less common authors were read in full or in the original.

${ }^{27}$ Cf. Dickey (n. 19), 221-4; Dionisotti (n. 19), 120-2 for the peculiarities of the reading list. 
Aristarchus (Prof. 13.3-4), and admired Citarius' Greek compositions, which he likened to that of Simonides of Ceos. Despite these accomplishments, Citarius gained little fame, as Ausonius laments that such things were no longer valued (esset Aristarchi tibi gloria Zenodotique | Graiorum, antiquus si sequeretur honos, Prof. 13.3-4). This comment may indicate that Greek was taught at a low level in Bordeaux and was not seen as equal to the more 'important' subjects of Latin rhetoric, or perhaps even Latin grammar. At the same time, although Ausonius himself may not have been intimately familiar with the works of Zenodotus, Aristarchus, or Simonides, he had enough knowledge of these figures to know that they would be ideal exemplars in praising Citarius and expected the readers of his Professores to understand the significance of the references. We might ascribe Citarius' superior Greek skills to the fact that he was born and presumably brought up in Sicily (Prof. 13.7-8), traditionally a stronghold of Greek culture and language in the Roman world. ${ }^{28}$

Students in Bordeaux could also learn Greek grammar from Urbicus. He is praised together with Crispus (Prof. 21), but while both are called Grammatici Latini et Graeci, Ausonius speaks specifically about Greek only in connection with Urbicus. His association with Crispus can nevertheless shed light on his precise function as Greek grammarian. Crispus taught 'the youngest boys, unskilled in speech, the simple signs of their new task, the alphabet' (qui primaeuos fandique rudes | elementorum prima docebas | signa nouorum, Prof. 21.4-6). Since Crispus taught basic literacy to the youngest students, indicating that he was an

${ }^{28}$ For the use of Greek in Sicily in Late Antiquity see K. Korhonen, 'Sicily in the Roman Imperial period: language and society', in O. Tribulato (ed.), Language and Linguistic Contact in Ancient Sicily (Cambridge, 2012), 326-369; A. De Angelis, 'Greek in Sicily in Late Antiquity', in G. Giannakis and V. Bubeník (edd.), Encyclopedia of Ancient Greek Language and Linguistics (Leiden, 2014), 94-101. 
elementary teacher or lower-level grammarian, it is probable that Urbicus, who is praised alongside Crispus in similar ways and with similar terminology, likewise taught only the younger students the basics of Greek grammar.

Further evidence that Greek was taught, albeit at a basic level, comes from the school days of Ausonius himself and his family members. Ausonius claims that he was a poor Greek student as a child, despite the best efforts of his teachers Corinthius and Spercheus (Prof. 8.916). ${ }^{29}$ Even if Ausonius is telling the truth and his Greek was never completely fluent, it is important to note that he had the opportunity to learn Greek as a young boy. Ausonius expected that his grandsons would have the same opportunity. In his Protrepticus ad nepotem Ausonius tells his grandson what to expect from school, saying that he will start by reading Homer and Menander (conditor Iliados et amabilis orsa Menandri | euoluenda tibi, Protrep. 46-7). ${ }^{30}$ Another of Ausonius' grandsons, Paulinus of Pella, also began his education in Gaul in the late fourth century by reading Greek texts. He reflects upon his early education in his Eucharisticos. ${ }^{31}$ Before advancing to Latin literature, Paulinus studied Plato and Homer:

Nec sero exacto primi mox tempore lustri

${ }^{29}$ This is similar to Augustine' professed distaste for learning Greek (August. Conf. 1.13.20$3)$.

${ }^{30}$ The Protrepticus, naturally, was intended for an audience much broader than just one small child, who at the time of its composition would have been too young to read it. The Protrepticus, and the message in it, would have circulated among Ausonius' fellow GalloRoman aristocrats, and Ausonius' summary of Latin and Greek education would have been familiar to these readers.

31 Though Paulinus was born in the East, he was in Bordeaux by the time he was three years old, when Ausonius held the consulship (i.e. 379); therefore, all of his formal education took place in Gaul (cf. Paul. Pell. Euch. 34-49). 
dogmata Socratus et bellica plasmata Homeri erroresque legens cognoscere cogor Ulixis. protinus et libros etiam transire Maronis uix bene conperto iubeor sermone Latino, conloquio Graiorum adsuefactus famulorum, quos mihi iam longus ludorum iunxerat usus; unde labor puero, fateor, fuit hic mihi maior, eloquium librorum ignotae apprehendere linguae.

Quae doctrina duplex sicut est potioribus apta ingeniis geminoque ornat splendore peritos, sic sterilis nimium nostri, ut modo sentio, cordis exilem facile exhausit diuisio uenam. (Paul. Pell. Euch. 72-84).

Full early, when the days of my first lustrum were well-nigh spent, I was made to read and learn the doctrines of Socrates, Homer's warlike fantasies, and Ulysses' wanderings. And I was bidden to traverse Maro's works as well, before I well understood the Latin tongue, used as I was to the converses of Greek servants with whom long pursuit of play had made me intimate; whereby, I affirm, this was too heavy a task for me, a boy, to grasp the eloquence of works in an unknown tongue. This double learning, as it is suited to more powerful minds and decks those skilled in it with a two-fold radiance, so its wide range soon drained dry the vein of my mind - too barren, as I now understand. ${ }^{32}$

It is clear that Paulinus read Plato and Homer in the original Greek. ${ }^{33}$ Not only does he distinguish his Greek instruction from his Latin with linguistic and temporal markers such as protinus to separate the two stages, but he stresses that it is the Latin language specifically that is difficult for him, since he was used to speaking to the Greek slaves that raised him. He also refers to his schooling as consisting of a 'double learning' (doctrina duplex ... gemino splendore), which recalls the conventional description of Greek and Latin bilingual instruction, utraque lingua doctus. ${ }^{34}$

32 Text and translation adapted from H. Evelyn-White, Paulinus Pellaeus: Eucharisticus (Cambridge, MA, 1921).

${ }^{33}$ dogmata Socratus would suggest Plato, but it could also mean a handbook of philosophy or sayings of philosophers.

${ }^{34}$ Cf. n. 2. 
In order to understand what level of Greek was being taught in Bordeaux and elsewhere in Gaul in this period, it is useful to consider the detailed study that Robert Kaster made regarding the teaching staff described by Ausonius in the Professores and other works. ${ }^{35}$ Arguing against previous interpretations, ${ }^{36}$ Kaster suggests that there was one Latin rhetor, two Latin grammarians, and one Greek grammarian in Bordeaux at any one time during the fourth century. According to Kaster's theory, the two Latin grammarians fulfilled separate roles - one each for primary and advanced grammatical instruction. Kaster gives three main arguments to support this theory: the rough number of grammarians commemorated in the Professores, the contemporary evidence for Trier and Milan, and the allusions to different levels of grammatical instruction throughout Ausonius' work. If Kaster is correct and there were two official Latin grammarians, one of whom taught elementary grammar, what does this say about the level of Greek instruction? If for every Greek grammarian there were two Latin grammarians, students would have spent less time on Greek and learnt it to a less advanced level - perhaps as a basis with which to be able to engage more fully and meaningfully with Latin literature and rhetoric. As we have seen, the evidence from Ausonius and other fourth-century sources support such a theory for Bordeaux, and evidence from elsewhere in Gaul also confirms such a structure of lower-level Greek teaching in the fourth century.

\footnotetext{
${ }^{35}$ Kaster (n. 16), 455-62.

${ }^{36}$ A. Booth, 'The academic career of Ausonius', Phoenix 36 (1982), 329-43; R. Green, 'Still waters run deep. A new study of the Professores of Bordeaux', CQ 35 (1985), 491-506.
} 
Students in Trier, for example, could learn Greek from the grammarian Harmonius, who was teaching there in the 370 s. ${ }^{37}$ It is possible that Harmonius taught both Latin and Greek grammar, since Ausonius compares him to famous scholars of both languages, and describes him as Cecropiae commune decus Latiaeque camenae, | solus qui Chium miscet et Ammineum ('Harmonius, glory alike of the Attic and the Latin Muse, who alone dost mingle wine of Chios and Aminaea' Ep. 10.31-2). Harmonius taught alongside the Latin grammarian Ursulus (Ursule collega nobilis Harmonio, Ep. 10.26). The presence of these two grammarians may shed light on a controversial edict in the Theodosian Code, which, as we will see, helps us to reconstruct the overall picture of Greek teaching in Gaul at this time.

In Gratian's so-called 'School Edict' (CTh 13.3.11, AD 376), salaries are set out for professors of Latin grammar, Latin rhetoric, and Greek grammar throughout the northern diocese of Gaul, and higher pay scales are fixed for grammarians and rhetors in Trier. While scholars have spent much time arguing over the broader implications of the edict, all have accepted the final clause regarding Greek grammarians at face value. The final clause of the edict seems to indicate that there was a lack of suitable candidates for Greek professorships in Trier, and this is often taken as indicative of the overall decline in Greek teaching in Gaul in the fourth and fifth centuries: Trevirorum uel clarissimae civitati uberius aliquid putauimus deferendum, rhetori ut triginta, item uiginti grammatico Latino, Graeco etiam, si qui dignus repperiri potuerit, duodecim praebeantur annonae ('Indeed, We suppose that a more generous amount should be bestowed upon the very renowned City of Trier, namely that thirty subsistence allowances shall be furnished a rhetorician, likewise twenty to a Latin grammarian,

\footnotetext{
37 This dating is based on Ausonius' letter to Ursulus (Ep.10), in which he discusses the emperor's new year's gifts. The date of the letter is 376, when Ausonius was quaestor to the emperor Gratian in Trier.
} 
and also twelve subsistence allowances shall be paid to a Greek grammarian, if anyone worthy to be chosen can be found'). ${ }^{38}$ This puzzling phrase can be better understood if we consider it alongside contemporary evidence of Greek teaching at the time, and take into account the changing role and status of Greek instruction within Latin schools in the late antique West.

A reconsideration of the edict shows that the situation regarding Greek was not so dire as previously assumed. Or, rather, the evidence from this edict does not necessitate such negative conclusions. This edict indicates that Greek teaching was not only taking place all across the northern diocese of Gaul, but that the position of a professor of Greek grammar was so prestigious as to be funded by the imperial government: per omnem dioecesim commissam magnificentiae tuae frequentissimis in civitatibus, quae pollent et eminent claritudine, praeceptorum optimi quique erudiendae praesideant iuuentuti: rhetores loquimur et grammaticos Atticae Romanaeque doctrinae ('Throughout every diocese committed to Your Magnificence, in the most thickly populated municipalities, which are powerful and eminent by their renown, all the best preceptors - We mean rhetoricians and grammarians of the Attic

${ }^{38}$ T. Mommsen and P. Meyer (edd.), Codex Theodosianus (Berlin, 1905); C. Pharr, M. Pharr, and T. Davidson (edd.), The Theodosian Code and Novels: and, the Sirmondian Constitutions (Princeton, 2001). Examples of pessimistic interpretations of this phrase include : Green (n. 9), 624: 'Greek teachers were in short supply at Trier (C. Th. 13.3.11)'; Green (n. 35), 494: 'it is clear that a Greek grammaticus could not always be found at Trier'; H. Sivan, 'Ausone et la légalislation impériale: L'exemple de CTh 13.3.11', REA 3-4 (1989), 47-53, at 52: 'L'espoir futile de trouver un professeur de grec digne d'occuper la chaire de grammaire dans la ville renvoie à la situation des études de cette langue en Gaule vers la fin du IVe siècle.' 
and Roman learning - shall preside over teaching the youth'). ${ }^{39}$ Moreover, if there was any possible doubt about finding suitable Greek grammarians, it was only in Trier. Throughout most of the edict the Greek professors are treated no differently from the Latin grammarians. When the professors are first mentioned they are specified as rhetores ... et grammaticos Atticae Romanaeque doctrinae, and the Latin and Greek grammarians are again referred to jointly when the salaries are set out: oratoribus uiginti quattuor annonarum e fisco emolumenta donentur, grammaticis latino uel graeco duodecim annonarum deductior paulo numerus ex more praestetur ('To those holding the rank of orators shall be granted the pay of twenty-four subsistence allowances from the fisc; to the grammarians, whether Latin or Greek, shall be paid twelve subsistence allowances, an amount slightly smaller, according to custom'). It is only in the final line of the edict, in the special pay scale set for Trier, that there is any differentiation between Latin and Greek grammarians. The salaries for rhetors and Latin grammarians in Trier are to rise from 24 to 30 , and 12 to 20 annonae respectively, but the Greek grammarian's salary in Trier is to remain at 12 annonae. The emperors add a caveat, saying that Greek grammarians will receive this salary of 12 annonae, si qui dignus repperiri potuerit. The word order makes it difficult to understand this phrase as referring to anything except the Greek professors, since it falls directly between the modifying adjective graeco and the salary they are to be paid: item uiginti grammatico latino, graeco etiam, si qui dignus repperiri potuerit, duodecim praebeantur annonae. At first glance the phrase si qui dignus repperiri potuerit seems to

\footnotetext{
${ }^{39}$ It was uncommon for professors' salaries to be paid by the state. Most teachers relied mainly on students' tuition fees and sometimes also drew municipal salaries. The emperors tended to pay salaries in special circumstances, and in cities that were important to them or to the state (i.e. Rome, Constantinople, and in this case Trier and its diocese, which was at that time the location of the imperial residence).
} 
indicate that there was not a shortage of teachers of Greek grammar in Trier, but rather a shortage of qualified ones, or ones who were 'comparable in distinction to the Latinists' ${ }^{40}$ If that were truly the case, surely the emperor would address this problem by trying to attract high calibre candidates to Trier by offering competitive salaries, but the salary of the Greek professor in Trier is to remain the same as in other parts of the northern diocese. ${ }^{41}$

It also seems peculiar that this was only a problem in Trier; according to the precise wording of the edict there is no suggestion that there would be trouble hiring suitable Greek grammarians anywhere else in northern Gaul. But why should a problem like this affect only what was presumably the most important and prestigious city in the region? Were the standards perhaps higher in Trier as it was the capital and imperial residence? Or maybe this phrase has more to do with Latin grammarians, and less with Greek. It would make sense that there would be more highly qualified Latinists in Gaul, since Latin was taught to a higher level (grammar and rhetoric) in schools than was Greek. And, since it is probable that Ausonius was instrumental in drafting this legislation, since he was quaestor at the time, the fact that he himself had worked as a Latin grammarian and rhetor may have augmented the prestige granted to these Latin positions in Trier. Since the salary for Greek grammarians in Trier is not any lower than any other Greek professor in northern Gaul, perhaps we should regard the final part of the edict as representing not a demotion or affront to Greek professors, but rather a special honour to professors of Latin grammar and rhetoric. Furthermore, if Greek grammarians taught only lower level grammar, while their Latin counterparts taught more advanced Latin literature,

\footnotetext{
${ }^{40} \mathrm{~S}$. Bonner, 'The edict of Gratian on the remuneration of teachers', AJPh 86 (1965), 113-37, at 135 .

${ }^{41}$ Cf. R. Kaster, ‘A Reconsideration of Gratian's School-Law', Hermes 112 (1984), 100-14, at 114 .
} 
it is therefore understandable that the Greek teachers would get a lower salary, even in Trier, the imperial residence. ${ }^{42}$

Whatever is meant by the special treatment of Greek grammarians in Trier, the edict generally paints a positive picture of teaching Greek in late fourth-century northern Gaul. It is expected that Greek grammar would be taught in all the provincial capitals in the northern diocese of Gaul, and the imperial government thought it worthwhile to fund these chairs of Greek grammar, providing compensation equal to Latin grammarians in all cities except Trier. This edict, in addition to the evidence from Ausonius and the Colloquium Celtis, shows that Greek had certainly not disappeared from the curriculum in the fourth century in Gaul. Nevertheless, its status and function had changed; it was no longer equal to Latin, as it had been for Quintilian and his contemporaries in the first century AD. Rather, Greek was taught at a lower level by grammarians who could be paid less than their Latin counterparts, and who sometimes taught 'part-time', or alongside Latin subjects.

\section{CASE STUDY:}

\section{CLAUDIANUS MAMERTUS AND SAPAUDUS IN FIFTH-CENTURY VIENNE}

\footnotetext{
${ }^{42}$ As we have seen above, Kaster's study of the grammarians of Bordeaux suggests that students learned Greek to a less advanced level in Bordeaux. As this paper shows, interest in Greek persisted in Gaul in this period, at least at the elementary level. Since there was still active teaching of Greek throughout Gaul, funded by the imperial government in the North, we should not assume that there was an overall shortage of qualified Greek grammarians in Trier or elsewhere in Gaul, but rather that the demand for Greek and use of it within Roman education and literary culture had changed by this period.
} 
An often-overlooked letter from the priest Claudianus Mamertus to Sapaudus, a teacher of Latin rhetoric, provides an opportunity to interrogate our preconceptions about the role and use of Greek in the classrooms of the late Latin West. A close reading of this mid-fifth century letter shows that some knowledge of Greek persisted, that it was valued by Gallo-Romans, and that Greek still had a place in the classrooms of late antique Gaul.

Claudianus Mamertus was a monk at Lérins and later became a priest in Vienne where his brother was bishop. He is best known for his philosophical treatise, De statu animae, written around 470 and dedicated to his friend Sidonius Apollinaris. The work represents one side of a theological and philosophical controversy that was taking place in southern Gaul at this time regarding the nature of the soul. Claudianus' work was provoked by a pamphlet, Quaeris a me, which was circulating around 469 and which argued for the corporeality of the soul. Claudianus' three-book response, in which he drew heavily on Neoplatonic philosophy, argued that the soul was incorporeal. The only other extant works of Claudianus are two letters: one to Sidonius, which is preserved within Sidonius' letter collections, and one to the rhetor Sapaudus. Sapaudus is also known from a letter from Sidonius (Ep. 5.10), and he taught rhetoric in Vienne in the $460 \mathrm{~s}$ and $470 \mathrm{~s} .{ }^{43}$

Claudianus' letter to Sapaudus is striking for its many references to Greek and Greek disciplines. Sapaudus' eloquence is described as 'mixed with Attic honey' (mixta uirtute Attici more mellis), and his students are 'imbued with the nectar of the Greek disciplines as if fed on Attic honey' (quae Graecarum quoque disciplinarum nectare imbuta ac si melle Attico

\footnotetext{
${ }^{43}$ This second letter is preserved in only one place - in a manuscript of the De statu animae from the $13^{\text {th }}$ century, which is housed in the Bibliothèque Nationale de France (MS Paris. 2165) and available to view online at:

https://gallica.bnf.fr/ark:/12148/btv1b100385810/f20.image.r=2165.
} 
pasta) ${ }^{44}$ These remarks about Greek can help to illuminate the perceptions of the value and use of Greek in late antique Gaul, and help us understand the changed role that Greek played in Latin classrooms at this time.

That Greek learning is of unmistakable importance in this letter is evident from the very first lines, as Claudianus opens his letter with a eulogy to Greece: 'Greece, the teacher of all disciplines and arts, especially in noble studies, has gone forth and has seized nearly the whole world with her manifold teachings' ${ }^{45}$ Claudianus laments the contemporary decline of education and literary values - a common trope in late Latin literature. ${ }^{46}$ Claudianus ponders whether we ought to blame human neglect or nature for this failure to cultivate the mind, and considers Cicero and Plato, both of whom left home to search for greater learning and achievement in foreign lands. He concludes that in his age what is lacking is not ingenia (ability), but studia for learning - which could mean either enthusiasm, or in fact actual studies. He therefore praises Sapaudus for his literary abilities and efforts as a teacher.

${ }^{44}$ A. Engelbrecht Claudiani Mamerti Opera CSEL 11 (Vienna, 1885), 203-6. Translations are my own. I have amended the text from acsi to $a c s i$, after it was brought to my attention by the editor, Bruce Gibson.

${ }^{45}$ Disciplinarum omnium atque artium magistra Graecia idcirco maxime nobilibus studiis prouecta est atque orbem paene totum multiplicibus complexa doctrina, Claud. Mam. Ep. ad Sapaud., p. 203.

${ }^{46}$ Cf. Sid. Ep. 2.10.1, 3.3.3, 4.17.2, 5.5.3, 5.10.4, 8.2, 8.5.3, Carm. 12.1-11; A century later, Gregory of Tours opened his History of the Franks with a similar regret: Decedente atque immo potius pereunte ab urbibus Gallicanis liberalium cultura litterarum, cum nonnullae res gererentur uel rectae uel inprobae. 
Claudianus continues with a highly rhetorical summary of the plight of the liberal arts which, though in many ways conventional in its sense and argument, stands out for its use of violent and martial vocabulary. The personified arts are not simply neglected, as the 'cultivation of the mind' was earlier in the letter, but are violently persecuted, feared, and rejected by Claudianus' fellow Gallo-Romans. ${ }^{47}$ In these desperate times, Sapaudus is the teacher par excellence in Gaul. ${ }^{48}$ Sapaudus' declamations are 'mixed with Attic honey' (mixta uirtute Attici more mellis) and Claudianus is especially pleased that Sapaudus teaches his students the Greek disciplines. Just like a bee who gathers drops of dew from the sky to fill her hive and nourish her offspring, Sapaudus gathers whatever is very learned (doctiora quaeque) from different authors and creates 'honeycombs of eloquence' (fauos eloquentiae) which produce 'honey of learning' (ingenii melle), on which his students are nourished and also 'imbued with the nectar of the Greek disciplines as if fed on Attic honey' (Graecarum quoque disciplinarum nectare imbuta acsi melle Attico pasta).

Claudianus' letter closes with advice about Sapaudus' use of literary models in his teaching. Unlike Sidonius, who, as Aaron Pelttari has argued, advocates reading contemporary

47 Grammaticam uti quandam barbaram barbarismi et soloecismi pugno et calce propelli, dialecticen tamquam Amazonem stricto decertaturam gladio formidari, rhetoricam ac si grandem dominam in angusto non recipi, musicen uero et geometricam atque arithmeticam tres quasi furias despui, posthinc philosophiam [atque] uti quoddam ominosum bestiale numerari, Claud. Mam. Ep. ad Sapaud., p. 204. Claudianus' personification of the liberal arts resembles that of Martianus Capella, though Claudianus includes philosophy instead of astronomy.

${ }^{48}$ penes Galliam nostram professionis tuae par unus et solus es, Claud. Mam. Ep. ad Sapaud., p. 205. 
authors as well as the older, canonical ones, ${ }^{49}$ Claudianus opts for a conservative view, explicitly forbidding contemporary 'juvenile rubbish' (puerilibus nugis) and prefers older, canonical models, namely Naevius, Plautus, Cato, Varro, Gracchus, Chrysippus, Fronto, and Cicero.

A close reading of one passage in particular, where Claudianus compares Sapaudus to a bee on Mt. Hybla, can shed light on Claudianus' and his contemporaries' perception of the value and role of Greek language and literature in education and literary culture, and Claudianus' interaction with and place within Greek and Latin literary traditions.

sed erui atque euelli infixa animo meo nequit declamationum tuarum suauitas mixta uirtute Attici more mellis, cui suapte natura indita sunt medela fortitudo dulcedo. quod in Hyblae iugis uolucris atque opifex apicula caelitus deciduum haustu capiens fabrefactis manso florigeris infundit filiorumque fabricatrix uirginitatis suae fetarum alit atque imbuit ubere fauorum, ita tu scilicet e summis auctoribus uelut e magnis montibus doctiora quaeque uelut thyma fraglantia et fecundiora ueluti quaedam florida praecerpens quos ingenii melle repleas eloquentiae conficis fauos, e quibus item discipulorum tibimet uelut filiorum numerositas dilecta formatur, quae Graecarum quoque disciplinarum nectare imbuta acsi melle Attico pasta, ut occeperit scientiae pennis strepere, eloquentiae fauos et ipsa conficiet.

But your declamations' charm, fixed in my mind, cannot be erased or torn away, mixed as it is with their strength, in the manner of Attic honey, which is endowed of its own nature with healing, strength, and sweetness. Because in the heights of Mt. Hybla a winged little workerbee, taking with a gulp what falls from heaven (i.e. dew), deposits it in its abode, made by skillful flower-bearers, and she who produces her own sons nourishes the offspring of her virginity and imbues [them] with the richness of his hives, thus you, picking from the greatest authors, as if from the highest mountains, whatever is most learned, as if fragrant thyme, and whatever is most blooming, as if something flowering, you complete these honeycombs of eloquence that you fill with the honey of learning, and from these likewise the multitude

${ }^{49}$ A. Pelttari (forthcoming), 'The rhetor Sapaudus and conflicting literary models in Sidonius Apollinaris and Claudianus Mamertus', in M. Onorato (ed.), Lo specchio del modello. Orizzonti intertestuali e Fortleben di Sidonio Apollinare (Naples, 2020 (est.)). 
of your beloved students, like sons, are formed; and they are imbued also with the nectar of Greek teachings as if fed by Attic honey, so that it begins to buzz with the wings of knowledge, and they themselves finish the honeycombs of eloquence.

The recurrent references to Greek throughout the letter, and particularly in this passage, are striking, especially since the letter is addressed to a late antique Latin rhetor. So far, as discussed above, most scholars argue that classical schools were in decline in the West in this period, and that the teaching of Greek had already largely ceased. This letter suggests that this situation was not as linear as the traditional narrative suggests. Examining how literary precedents may have informed Claudianus' choice of words in this passage may help to make his meaning clearer. Especially intriguing are the phrases 'Attic honey' and 'nectar of the Greek disciplines'. Honey or nectar is a topos in Greek and Latin literature, conventionally associated with purity, eloquence, and clarity of speech. This is seen consistently throughout classical literature, from Homer to Sedulius. ${ }^{50}$ In the De divinatione, for example, Cicero gives examples of omens and their interpretations that came to pass. Among these is the story that bees landed on the lips of Plato when he was an infant. This event was thought to foreshadow the philosopher's future eloquence. ${ }^{51}$ Ausonius likewise connects honey with eloquent speech. In a letter to the rhetor Paulus, Ausonius states, sic tibi sint Musae faciles, meditatio prompta $\mid$ et memor, et liquidi mel fluat eloquii ('So be the Muses gracious to thee, thy conception ready, thy memory sound, and free thy flow of melting honey', Ep. 8 vv.17-18), and Ausonius

\footnotetext{
${ }^{50}$ See e.g. Hom. Il. 1.249; Sedulius. Carm. Pasch. praef. 13-14.

${ }^{51}$ Cic. Div. 1.36: At Platoni cum in cunis paruulo dormienti apes in labellis consedissent, responsum est singulari illum suauitate orationis fore. Ita futura eloquentia prouisa in infante est.
} 
regularly describes Nestor, the Homeric character famed for sound counsel and eloquent speech, with honeyed lips (Aus. Grat. Act. 9, Prof. 21.22-24, Ep. 9b v.14).

Given the ubiquity of honey as a metaphor in classical literature, Claudianus' use of honey in reference to a Latin rhetor in this instance is not new nor out of place. Neither is the comparison between a reader or teacher and a bee who makes honey by gathering little bits from flowers and plants. We see a similar scenario described in the preface to Macrobius' Saturnalia, and Macrobius clearly took this idea from Seneca's Epistle 84, where a reader gathering ideas is compared to a bee taking nectar from a variety of flowers. ${ }^{52}$ While neither honey nor bees are strange in the context of a letter to a Latin rhetor, it is noteworthy that Claudianus specifies not once, but twice that it is 'Attic honey'. Aside from appearing in many medical texts and throughout Pliny's Natural Histories, in other literary texts Attic honey is conventionally described as the best honey, especially in comparison with honey from Corsica or Sardinia, both of which are traditionally bad tasting. ${ }^{53}$

Another jarring detail in this passage is the association between 'Attic honey' and Mt. Hybla, since 'Attic honey' should come from Mt. Hymettus, in Athens. Hybla (in Sicily) and Hymettus (in Athens) are associated with honey throughout Latin literature. Although they are often mentioned in the same breath, there is almost always a clear distinction between Hyblaean and Hymettian (variously termed Attic, or Cecropian) honey, though some authors admit that Hyblaean honey can come close or even challenge its Greek counterpart. ${ }^{54}$

\footnotetext{
${ }^{52}$ Macrob. Sat. praef. 5-6; Sen. Ep. 84.3-7.

${ }^{53}$ E.g. Plin. HN 19.168; Scribonius Largus, passim; Hor. Ars P. 375; Verg. Ecl. 7.41, 9.30.

${ }^{54}$ On Hyblaean honey, see W, Clausen. A Commentary on Virgil Eclogues (Oxford, 1994), at 52, in his comment on Verg. Ecl. 1.54. Strabo commented on the good quality of Mt. Hybla's honey (Strabo 6.2.2), and Varro also considered it the best (Varro Rust. 3.16.14). Mt. Hybla's
} 
Given this solid literary tradition, it is unusual that Claudianus conflates Attic honey and Roman Mt. Hybla. Claudianus may have been mistaken about his geography, which could have easily happened if he had read Virgilian commentaries, such as Servius', which is unclear about the exact location of Mt. Hybla. ${ }^{55}$ But if we conclude that Claudianus was mistaken about the location of Hybla - that is, if he thought it was in Athens, or was possibly in Athens - this would add a further reference to Greece and would strengthen the argument that these references are significant in some way to Sapaudus and his role as a teacher of Latin rhetoric.

honey was a popular theme in Latin poetry, from Virgil $(E c l .1 .54,7.37)$ to Late Antiquity: Ov. Ars am. 2.517, 3.150, Tr. 5.6.38, 13.22, Pont. 2.7.26, 4.15.10; Lucan, 9.291; Stat. Silv. 2.1.478, 3.2.117-8; Mart. 2.46.1-2, 5.39.3, 7.88.8, 9.26.4, 11.42, 13.104, 13.105.1; Sil. Pun. 14.2330, 192-200; Claud. De rapt. Pros. 2.125.

${ }^{55}$ Servius may have been led astray by some curious references to Hybla in Statius, such as Achil. 1.553-9:

Conclamant Danai stimulatque Agamemno uolentes.

laxantur coetus resolutaque murmure laeto

agmina discedunt, quales iam nocte propinqua

e pastu referuntur aues, uel in antra reuerti

melle nouo grauidas mitis uidet Hybla cateruas.

nec mora, iam dextras Ithacesia carbasus auras

poscit, et in remis hilaris sedere iuuentus.

Servius, In Vergilii Bucolicon Librum 1.54 : hyblaeis Hybla, quae postea Megara, oppidum Siciliae: uel locus in Attica, ubi optimum mel nascitur. depasta florem depastum florem habens. salicti uirgulti genus, eo quod salit et surgit cito. hic uocat rusticum ad dulcia, quae sunt in rebus, quibus delectatur. 
It is possible that Claudianus referred to Hybla as Attic because of its association with Greek poetry through Theocritus. Moreover, Sicily, though technically part of the 'Latin' world, was traditionally associated with Greek language and continued to have a Greek-speaking population in Late Antiquity. ${ }^{56}$ If we accept that Claudianus was aware of the rich literary tradition of Hybla and Hymettus, and was consciously drawing on this and blending the two in this passage, what does that mean for Sapaudus, Claudianus, and teaching in fifth-century Gaul?

As we have seen, Attic honey is conventionally the best honey, so perhaps Claudianus uses 'Attic honey' to praise Sapaudus. But it is possible to take this metaphor further. Attic honey is the best honey, but for Claudianus it is associated with bees that work on Hybla in Sicily, that is, in Roman territory known for Greek language. It is Roman pupils that are fed by the 'Attic honey' and the 'nectar of the Greek disciplines', so it is Roman students - Sapaudus' students in fifth-century Vienne - who get the benefits of Greek learning. By first discarding the conventional dismissal of Greek knowledge in the West, and by considering this passage with more generous eyes, we can learn something about Sapaudus' pedagogical practice and the place of Greek in his classroom, and, more broadly, in the classrooms of fifth-century Gaul. When Claudianus speaks of the 'Attic honey' and 'nectar of the Greek disciplines' that sweeten Sapaudus' declamations and nourish his students, he is perhaps alluding to the contemporary use of Greek in Latin education and literary culture. That is, Sapaudus used Greek - Greek language, learning, and Greek rhetorical style, not necessarily in original language - to instruct his students in Latin language and style and improve their understanding and composition of Latin rhetoric. In Claudianus' metaphor Sapaudus is likened to the bee and his teaching to the

\footnotetext{
56 The Greek grammarian Citarius, for example, moved to Bordeaux from Sicily in the midfourth century (Aus. Prof. 13). Cf. n. 28.
} 
honeycomb. Like a bee collects dew from the sky and uses it to construct her hive and nourish her offspring, Sapaudus takes excerpts from classical authors, brings them together alongside his own learning and eloquence, and shares it with his students, adding Greek learning ('the nectar of the Greek disciplines') to the mix, so that his students are fed by 'Attic honey'. 'Greek nectar' is just one of many elements that nourish Sapaudus' students. Greek plays a similar role for Sapaudus as it did for Servius in his commentary. For Sapaudus, Greek is a pedagogical tool with which he can strengthen his students' understanding and appreciation of Latin rhetoric and enrich their education.

On the other hand, the reference to 'Attic honey' and 'Greek disciplines' may simply serve as a reflection of Claudianus' own interests. We know that Claudianus valued Greek and probably read it fluently and preferred more 'conservative' authors, and the Greek sources of Latin learning. ${ }^{57}$ Sidonius Apollinaris, one of Claudianus' contemporaries and a wellconnected and prolific letter-writer, highlights Claudianus' knowledge of Greek and Latin and compares him to famous authors of both languages. In a letter to him (Ep. 4.3), Sidonius lavishes praise upon Claudianus, comparing him to a whole host of famous Greek and Roman figures (from reality and mythology) in a series of impossibly long lists of authors, orators, philosophers, politicians, church fathers, and mythological figures. ${ }^{58}$ Sidonius mentions Claudianus' 'acquaintance with Greek and Latin lore' and in a poem written on death of his friend, says that 'under his teaching three literatures were illumined, Latin, Greek, and Christian'. 59

\footnotetext{
${ }^{57}$ Pelttari (n. 48).

${ }^{58}$ Sid. Ep. 4.3.1, 6, 7.

${ }^{59}$ Sid. Ep. 4.3.6-7; 4.11.6 v.4-5.
} 
Claudianus was not the only one in Sidonius' circle of fifth-century Gallo-Roman litterateurs who was interested in Greek. Sidonius also explicitly praises the younger and elder Consentius for their knowledge of Greek. The elder Consentius was proficient in both Latin and Greek (Consenti...patrem, | illum cui nitidi sales rigorque | Romanus fuit Attico in lepore, Carm. 23.108-110) and is compared to the seven sages and other Greek and Latin authors (101-144, 145-169). The younger Consentius followed in his father's literary footsteps. He was renowned for his poetry in both Latin and Greek (Carm. 23.5-7, 20-8, 204-9; Ep. 8.4.2; 9.15.1 vv.19-34) and was trusted by the emperor Valentinian III to act as interpreter on diplomatic missions to the Greek-speaking court of the Eastern emperor Theodosius II (Carm. 23.228-40). Despite his overall negative conclusions about Greek in late antique Gaul, Courcelle concludes, both from Sidonius' description and from Claudianus' own literary output, that Claudianus is the rare exception to the rule, and that he probably did read Greek literature firsthand. Courcelle even concedes that, though most of Sidonius' references to Greek authors are rhetorical, Sidonius might have known at least some Greek. ${ }^{60}$ On the other hand, many scholars are persistent in their conviction that Greek had disappeared from education and literary culture by this period. In his study of philosophical knowledge in fifth-century Gaul, Charles Brittain argues that neither Claudianus nor Sapaudus nor Sidonius knew Greek, insisting that the references to Greek authors and literature in Sidonius and Claudianus only demonstrates that they both knew about a wide range of Greek and Roman authors, not that either had or was able to read these texts in the original Greek. He further argues, 'when Sapaudus gave his students a smattering of Greek learning to improve their eloquence, he did

${ }^{60}$ Courcelle (n. 8), 238-58. 
not need to teach them Greek first to do it'. ${ }^{61}$ Isabella Gualandri is likewise sceptical about Sidonius' familiarity with Greek language and literature. She argues that although Sidonius often uses Greek words and clearly has an appreciation of the cultural value of Greek literature, his works do not betray anything beyond knowledge of technical vocabulary and basic knowledge that he could glean from scholastic material and manuals. ${ }^{62}$ Based on the evidence and praise from Sidonius, there is no reason to doubt that at least Claudianus and the elder and younger Consentius actually knew Greek. ${ }^{63}$ Although Sidonius praises many of his

${ }^{61}$ C. Brittain, 'No place for a Platonist soul in fifth-century Gaul? The case of Claudianus Mamertus', in R. Mathisen and D. Shanzer (edd.), Society and Culture in Late Antique Gaul: Revisiting the Sources (Aldershot, 2001), 239-62, at 245.

${ }^{62}$ On Sidonius' use and knowledge of Greek see Gualandri (n. 7); Courcelle (n. 8), 251-62; A. Cameron, The Last Pagans of Rome (Oxford, 2011), 546-54; S. Condorelli, 'Improvisation and poetical programme in Sidonius, Ep. 9.13', in J. Van Waarden and G. Kelly (edd.), New Approaches to Sidonius Apollinaris (Leuven, 2013), 111-32, at 129-30; Also cf. D. Shanzer and I. Wood (edd.), Avitus of Vienne. Letters and Selected Prose (Liverpool, 2002), 62, who in describing the similarities between Sidonius and Pliny's letter collections say, 'almost all of Sidonius' Greek words come from Pliny'.

${ }^{63}$ Although these are the only individuals explicitly linked with proficient Greek knowledge, we may infer through indirect evidence that others were also at least interested in Greek culture. For example, as noted above, Onorato (n. 14) suggests that Sidonius interacts with Ausonius' 'macaronic' poem to Paulus in his own poem to the Bordeaux teacher Lampridius. This indicates that both Sidonius and Lampridius would have been able to appreciate Ausonius' word play and use of Greek forms. Others among Sidonius' correspondents are also praised for their poetic virtuosity in Latin, including Petrus (Sid. Ep. 9.13, 9.15 vv.39-43, Carm. 9.307- 
correspondents for their learning and literary abilities, only these few are singled out as being experts in Greek, suggesting that such compliments were not simply a way to indicate that someone was especially learned, but rather that these few individuals actually did value and know Greek. ${ }^{64}$

\section{CONCLUSION}

Despite the entrenched view that knowledge of Greek had virtually disappeared in the late antique West, evidence from late antique Gaul shows that Greek remained a fundamental part of the classical schools throughout Gaul in this period. For too long scholars have relied on previous assumptions that were themselves based on flawed methodologies for analysing Latin literary sources. Therefore, if we want to understand the status of knowledge of Greek at the time, we cannot continue to rely on these past studies as these will always lead to the incorrect conclusion that almost no educated late antique westerner knew Greek. This article has

8), Paulus (Sid. Ep. 1.9), Leo (Sid. Ep. 9.13 v.20), Domnulus, and Severianus (Sid. Ep. 9.13.3). Given the fact that Greek mythology and culture had always been foundational to Latin literature, it is plausible that these Gallo-Romans who had literary ambitions would also have had an interest in Greek culture, and perhaps more than a passing knowledge of Greek language and literature. At the same time, we should not automatically assume that all fifth-century Gallo-Romans with literary ambitions knew Greek.

${ }^{64}$ Other instances where Sidonius appeals to Greek authorities or authors in his praise of friends is mainly in his lists of philosophical figures, which while it could very well signal a knowledge of Greek itself, since much philosophical writing, including late antique Neoplatonic texts, was in Greek, it might also be a way to indicate familiarity with philosophical ideas. An example is Sidonius' praise of Faustus, Ep. 9.9.14-15, or his list in his panegyric to Anthemius, Carm. $2.156-192$. 
challenged and corrected our previous assumptions, providing a reassessment of our sources for Greek and a new way of conceptualizing the place and function of Greek in education and literary culture in late antique Gaul.

A reinterpretation of fourth-century sources, and a case study from fifth-century Gaul, indicates that Greek was still taught in the classrooms of Late Antiquity, though those who learned, read, and wrote in Greek were probably fewer in number than in earlier periods. It is also apparent that at this time engaging with Greek and knowing Greek meant something different. While a foundational knowledge of Greek was widespread among the educated class, further engagement and interest in Greek literary texts was less common. That is not to say, however, that there was an ignorance of Greek, or that knowledge of Greek had disappeared. Greek still existed in late antique western classrooms and was still a part of Latin literary culture, but it was taught at a lower level to young students, and in some cases may have been perceived and used as a pedagogical tool for learning and understanding Latin texts. For late antique Gallo-Romans such as Ausonius, Claudianus Mamertus, Sapaudus, and Sidonius, Greek remained a valuable and integral part of their education and literary endeavours. ${ }^{65}$

Ghent University

ALISON JOHN

alison.john@ugent.be

${ }^{65}$ This article would not have existed without the help of many colleagues. I would like to thank Gavin Kelly, Lucy Grig, Aaron Pelttari, Calum Maciver, Sigrid Mratschek, Roger Rees, and Zubin Mistry, who offered guidance and suggestions at various stages of the writing process. My argument was furthered sharpened from feedback at the CA conference in Edinburgh and the ISLALS conference in Bryn Mawr/Haverford. This article took its final shape as a result of valuable comments from the anonymous reviewers and the editor Bruce Gibson. I also must thank the University of Edinburgh, the DAAD, and SSHRC for supporting the research for this article. Any remaining mistakes are my own. 